\title{
Trial Burn Activities for a Mixed Waste Incinerator
}

by

M. Birk

Westinghouse Savannah River Company

Savannah River Site

Aiken, South Carolina 29808

A document prepared for INTERNATIONAL CONFERENCE ON INCINERATION AND THERMAL TREATMENT TECHNOLOGIES at Salt Lake City, UT, USA from 5/11/98 - 5/15/98.

DOE Contract No. DE-AC09-96SR18500

This paper was prepared in connection with work done under the above contract number with the U. S.

Department of Energy. By acceptance of this paper, the publisher and/or recipient acknowledges the U. S. Government's right to retain a nonexclusive, royalty-free license in and to any copyright covering this paper, along with the right to reproduce and to authorize others to reproduce all or part of the copyrighted paper. 


\section{DISCLAIMER}

This report was prepared as an account of work sponsored by an agency of the United States Government. Neither the United States Government nor any agency thereof, nor any of their employees, makes any warranty, express or implied, or assumes any legal liability or responsibility for the accuracy, completeness, or usefulness of any information, apparatus, product, or process disclosed, or represents that its use would not infringe privately owned rights. Reference herein to any specific commercial product, process, or service by trade name, trademark, manufacturer, or otherwise does not necessarily constitute or imply its endorsement, recommendation, or favoring by the United States Government or any agency thereof. The views and opinions of authors expressed herein do not necessarily state or reflect those of the United States Government or any agency thereof.

This report has been reproduced directly from the best available copy.

Available to DOE and DOE contractors from the Office of Scientific and Technical Information, P. O. Box 62, Oak Ridge, TN 37831; prices available from (423) 576-8401.

Available to the public from the National Technical Information Service, U. S. Department of Commerce, 5285 Port Royal Road, Springfield, VA 22161. 


\section{DISCLAIMER}

Portions of this document may be illegible electronic image products. Images are produced from the best available original document. 


\title{
TRIAL BURN ACTIVITIES FOR A MIXED WASTE INCINERATOR
}

\author{
Marcia B. Birk \\ Westinghouse Savannah River Company \\ Consolidated Incineration Facility \\ Aiken, South Carolina 29802
}

\begin{abstract}
The Consolidated Incineration Facility (CIF) is located on the Savannah River Site (SRS), owned by the U.S. Department of Energy and managed by BNFL, Inc. for the Westinghouse Savannah River Company. SRS received permits from the South Carolina Department of Health and Environmental Control (SCDHEC) and the U.S. Environmental Protection Agency (EPA), Region IV to construct and operate the CIF, a hazardous, radioactive and mixed waste incinerator. This paper presents the results of the trial burn conducted on the CIF in April 1997 which is the initial demonstration of compliance with the permits. The incinerator is currently operating under approved post-trial burn conditions while the trial burn results are being evaluated. A final operating permit is anticipated in the fall of 1998.
\end{abstract}

\section{INTRODUCTION}

The Consolidated Incineration Facility (CIF), located at the Savannah River Site in Aiken, SC, conducted a Trial Burn from April 14 to April 20, 1997 to demonstrate compliance with the Resource Conservation and Recovery Act (RCRA) and the Clean Air Act (CAA). This paper describes the CIF incineration process, outlines the development of the Trial Burn Plan, and presents the results of the Trial Burn.

\section{DESCRIPTION OF THE INCINERATION PROCESS}

The CIF was designed to incinerate hazardous, radioactive and mixed waste. It consists of a waste and auxiliary fuel feed system, the incinerator system, the air pollution control system, and a process to solidify the waste residuals. Figure 1 presents a schematic of the system.

\section{Waste Feed System}

The incinerator is designed to process solid waste, high heating value waste, and aqueous waste. Solid waste is fed to the rotary kiln primary combustion chamber in 21-cubic-inch boxes via a conveyor and ram feeder. The majority of the organic liquid waste is collected in two 4200-gallon tanks and injected into the primary combustion chamber via a vortex burner with a wet steam atomization pressure of approximately $15 \mathrm{psig}$. A benzene liquid waste is injected into the secondary combustion chamber via a steam atomized vortex burner. This waste stream is piped directly from the Defense Waste Processing Facility via a transfer line dedicated to the DWPF benzene byproduct waste stream. The aqueous 


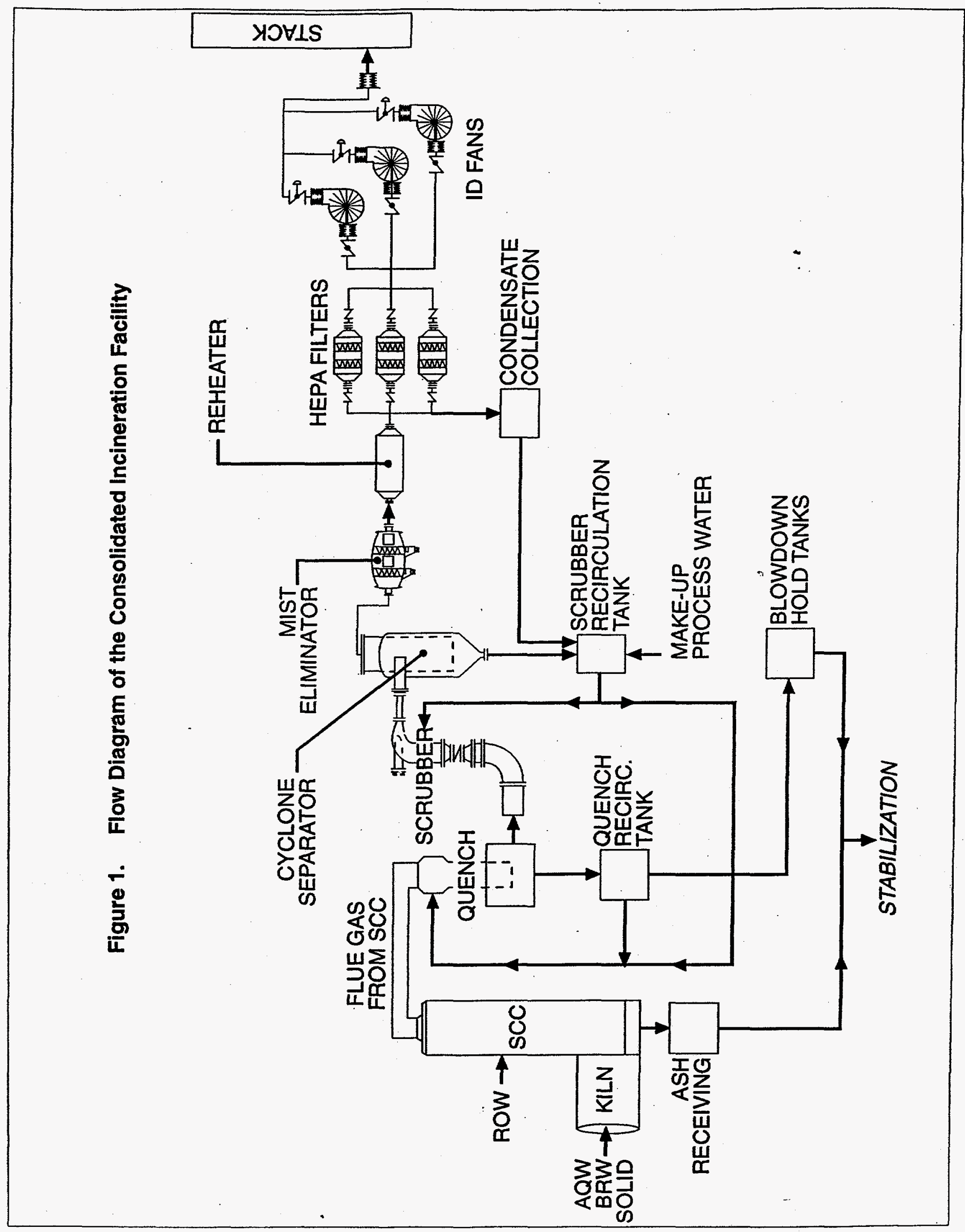




\section{Insert Figure 1 here.}

waste is collected in two 6500 tanks and injected into the rotary kiln via a mechanical nozzle with 80-120 psig steam atomization. Auxiliary fuel is fed to both chambers to maintain minimum temperatures.

\section{Incinerator System}

The incinerator system consists of an 8-foot diameter by 25-foot long horizontal rotary kiln coupled to a vertical secondary combustion chamber (SCC) that has a 7-foot diameter and 21-foot height. The rotary kiln, the SCC and the cross-over duct leading from the SCC are fabricated of carbon steel lined with high temperature refractory and the two chambers have a combined heat release of 27.9 million Btu/hr. The normal operating temperature in the rotary kiln is approximately $1600^{\circ} \mathrm{F}$ and the SCC temperature is approximately $1800^{\circ} \mathrm{F}$. The approximate residence time is 30 minutes for solid waste and 2 seconds for the gases. The ash that is not entrained in the offgas empties into a water tank at the bottom of the SCC. The water serves to provide a vacuum seal and acts as a quench and wetting agent for the ash.

\section{Air Pollution Control System}

The offgas pollution control system consists of an adiabatic quench chamber, a

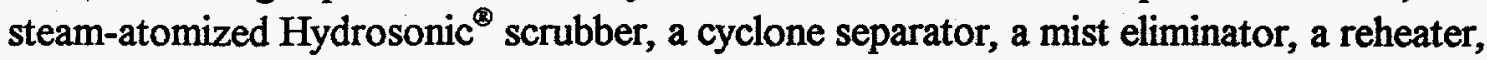
and three banks of HEPA filters, two of which are on line during operation. The HEPA filters were included in the design primarily for the removal of radioactive particulate matter. To minimize secondary waste, the quench water is recirculated until it reaches a preset suspended or dissolved solid limit. At that point, the quench water is transferred to two 6500-gallon blowdown hold tanks.

\section{Ash and Blowdown Solidification System}

Ash is removed from the water tank at the base of the SCC using a back-hoe-type device and deposited into 55-gallon drums. Cement and water are added in controlled amounts and the drum is mixed by tumbling. This produces a solidified waste product suitable for land disposal. Similarly, the blowdown is transferred from the blowdown hold tanks in measured amounts and processed into a concrete matrix. During the Trial Burn, this process was not used and the wet ash and blowdown were shipped to a commercial hazardous waste treatment and disposal facility.

\section{TRIAL BURN PLAN DEVELOPMENT}

The development of the Trial Burn Plan was initiated in 1988 at which time the only requirements were to demonstrate ash feed, chlorine emissions and $99.99 \%$ destruction removal efficiency (DRE) of principal organic hazardous constituents (POHC). With the proposal of the BIF rules in 1989 and the draft Combustion Strategy in 1993, CIF was required to go through several iterations of the development of the plan. 
TABLE I

Composition of Liquid Waste Simulants

\begin{tabular}{|c|c|c|c|c|}
\hline \multicolumn{2}{|c|}{$\begin{array}{c}\text { Aqueous Waste } \\
\text { (AQW) }\end{array}$} & \multicolumn{2}{c|}{$\begin{array}{c}\text { Radioactive Organic Waste } \\
\text { (ROW) }\end{array}$} & wtended Radioactive Waste \\
(BRW)
\end{tabular}

TABLE II

Composition of POHC and Metal Spiking Mixtures

\begin{tabular}{|c|c|c|c|c|c|}
\hline \multicolumn{2}{|c|}{$\begin{array}{l}\text { POHC Spiking Solutions } \\
\text { (to both ROW and BRW) }\end{array}$} & \multicolumn{2}{|c|}{$\begin{array}{l}\text { Metal Nitrate Spiking } \\
\text { (to AQW) }\end{array}$} & \multicolumn{2}{|c|}{$\begin{array}{l}\text { Metal Oxide Suspension Spiking } \\
\text { (to AQW) }\end{array}$} \\
\hline Component & $w t \%$ & Component & wt \% & Component & $w t \%$ \\
\hline Chlorobenzene & 50 & Water & $59.8^{\circ}$ & Water & 78.5 \\
\hline \multirow[t]{6}{*}{ Tetrachloroethylene } & .50 & Nickel Nitrate Hexahydrate & 30.4 & Antimony Oxide & 19.0 \\
\hline & & Chromium Nitrate Nonahydrate & 8.87 & Suspension Agent (clay) & 1.5 \\
\hline & & Lead Nitrate & 1.63 & Mercuric Oxide & 0.52 \\
\hline & & Beryllium Nitrate Trihydrate & 0.17 & Arsenic Oxide & 0.42 \\
\hline & & Cadmium Nitrate Tetrahydrate & 0.06 & Selenium Suifide & 0.1 \\
\hline & & Barium Nitrate & 0.05 & & \\
\hline
\end{tabular}


TABLE III

Composition of Containers of Solid Waste Simulants

\begin{tabular}{|c|c|c|c|}
\hline Component & $\begin{array}{c}\text { Condition 1 } \\
(\mathbf{g})\end{array}$ & $\begin{array}{c}\text { Condition 2 } \\
\mathbf{( g )}\end{array}$ & $\begin{array}{c}\text { Condition 3 } \\
(\mathrm{g})\end{array}$ \\
\hline Hexachloroethane & 383 & 387 & 154 \\
\hline Naphthalene & 446 & 436 & 195 \\
\hline Hexachlorobenzene & 11 & 11 & 11 \\
\hline Chlorobenzene & 24 & 17 & 20 \\
\hline Tetrachloroethylene & 17 & 37 & 17 \\
\hline Toluene & 37 & 32 & 37 \\
\hline Xylene & 32 & 147 & 32 \\
\hline $1,1,1-$ Trichloroethane & 147 & 0.7 & 147 \\
\hline Copper Chloride Dihydrate & 0 & 9545 & 7.8 \\
\hline Polyvinylchloride & 10072 & 566 & 4489 \\
\hline Clay Absorbant & 454 & & 6123 \\
\hline
\end{tabular}


Both of these criteria were imposed upon CIF by the EPA under omnibus authority. As a result, the plan was changed to include gathering data to support a health risk assessment requiring PIC precursors and twelve metal feeds, and to utilize the Exposure Assessment Guidance in POHC selection to ensure that chemicals with risks were used.

The Trial Burn Plan consisted of demonstration of incineration at three distinct test conditions. Condition 1 (Runs 1,2, and 3) was operation of the incinerator at maximum temperatures in the combustion and maximum stack velocity. Condition 2 (Runs 4, 5, and 6) was operation of the incinerator at maximum liquid feed rates and Condition 3 (Runs 7 , 8, and 9) was operation of the incinerator with maximum solid feed rate, minimum combustion zone temperatures, and maximum kiln rotation. Chlorine and metal feed rates were held constant over all runs.

Given that the actual waste feed at the Savannah River Site is predominantly radioactive, and that there were insufficient quantities of a consistent waste stream, the Trial Burn was conducted using prepared waste simulants which were representative of expected CIF wastes. Two different organic waste streams were prepared to simulate the blended radioactive waste (BRW) that would be fed to the rotary kiln and the radioactive organic waste (ROW) that would be fed to the SCC. In addition, one aqueous waste (AQW) simulant and boxes of solid waste for each of the three conditions were prepared. The POHCs were spiked into the BRW feed line and the ROW feed line. The metals were spiked into the aqueous waste stream at two points in the feed line. Eight metals were introduced into the feed line in a nitrate mixture and four metals were fed via an oxide suspension. The composition of each of the simulated wastes is shown in Tables I, II, and III.

\section{TRIAL BURN IMPLEMENTATION}

Radian International of Austin, TX was contracted to perform the stack testing and chemicals were procured from Noah Technologies of San Antonio, TX. Prior to the actual Trial Burn performed in April 1997, two mini-burns were conducted which were designed to replicate the planned conditions of the Trial Burn. The first of these miniburns, Pre-Trial Burn I, was performed in December 1995. This was the first opportunity to determine how the plant and personnel would function with hazardous chemicals. As the test progressed, the plant experienced both equipment problems and operating problems. After much difficulty was encountered in maintaining temperatures and feeds to complete the first condition, the mini-burn was postponed to evaluate lessons learned and to improve the process. Although on the surface this test could be considered a failure, the experience was invaluable in leading CIF to a successful Trial Burn. It showed that a much more disciplined approach was needed to get the plant and all personnel ready for the final test. A multi-disciplined Trial Burn Committee was dedicated to identifying, assigning, and tracking over 120 action items that led to the second phase, Pre-Trial Burn II. Several changes were made to the test plan and were negotiated with SCDHEC. The decision was made to have all of the chemical simulants pre-mixed by Noah Technologies and B3 Systems of Raleigh, NC was contracted to perform the spiking procedures. The 
several months following Pre-Trial Burn I provided the opportunity for enhanced personnel training and extensive practice in running the plant.

The Trial Burn Committee established several readiness indicators which the facility would meet prior to Pre-Trial Burn II. These indicators included: 1) maintain the actual trial burn conditions for at least one day per condition, 2) maintain at least $75 \%$ of the trial burn waste feed rate on a consistent daily basis, 3) if a waste feed cutoff occurred, recover from the cutoff within 10 minutes, 4) Shift Supervisors would sign off all 48 systems were ready, and 5) no residual secondary waste remained in inventory. In December 1996 the plant and personnel were ready and Pre-Trial Burn II was completed in four days. It was designed to replicate the Trial Burn at one run for each condition and proved to be a very reliable indicator of the Trial Burn Results. One of the more important benefits of Pre-Trial Burn II was that it gave the operators confidence that they could be successful in the Trial Burn. The Trial Burn was completed in April 1997. Nine tests, three runs of each of the three conditions, were completed in seven days. The final report was submitted to EPA and SCDHEC on July 17, 1997 and is currently being reviewed. CIF anticipates a final operating permit in the fall of 1998.

\section{RESULTS}

Table IV summarizes operating parameters for each of the three conditions. The values in this table are the average values over the three runs for each condition. Table $V$ presents the results of the Trial Burn and compares the results to the proposed revised MACT standards issued by EPA in May 1997. The results indicate that CIF meets all current standards and permit limits for destruction and removal efficiency (DRE) and emissions of particulate matter, $\mathrm{HCl}$ and $\mathrm{Cl}$, carbon monoxide, and nitrogen oxides. However, if the currently proposed MACT standards are promulgated, changes will need to be made to the facility to mitigate mercury and dioxin emissions to meet those standards. CIF is currently investigating the probable causes of the high dioxin generation and the low mercury removal efficiency. All of the Trial Burn results can be found in Reference 1.

\section{LESSONS LEARNED}

The most important lessons learned were to be prepared and to keep all personnel informed of the progress made toward meeting the goals of the facility. Each of the 48 systems were thoroughly reviewed for readiness. One of the more critical systems to the success of the Trial Burn is the Distributed Control System (DCS). It is important to ensure that the data collected by the DCS is easily retrievable in a form that is useful in preparing the final Trial Burn Report. Practice is essential in preparation. The spiking systems were initially operated on water and fuel oil, then with nonhazardous similar materials (zinc oxide and ferrous nitrate) and finally with the real metal spiking material. During the Pre-Trial Burn II, it was found that the spiking pumps were oversized and difficult to control and this was remedied prior to the Trial Burn. 
TABLE IV

Summary of Operating Conditions for CIF Trial Burn

\begin{tabular}{|c|c|c|c|}
\hline Parameter & Condition 1 & Condition 2 & Condition 3 \\
\hline Thermal Capacity (MMBtu/hr) & 23.9 & 21.2 & 16.7 \\
\hline Solid Waste Feed (lb/hr) & 479 & 481 & 957 \\
\hline BRW Waste Feed (lb/hr) & 116 & 369 & 108 \\
\hline AQW Waste Feed (lb/hr) & 448 & 939 & 297 \\
\hline ROW Waste Feed $(\mathrm{lb} / \mathrm{hr})$ & 75 & 185 & 75 \\
\hline RK Fuel Oil (lb/hr) & 432 & 108 & 181 \\
\hline SCC Fuel Oil (lb/hr) & 373 & 173 & 259 \\
\hline RK Temperature $\left({ }^{\circ} \mathrm{F}\right)$ & 1804 & 1461 & 1396 \\
\hline SCC Temperature ( $\left.{ }^{\circ} \mathrm{F}\right)$ & 1949 & 1599 & 1595 \\
\hline CGVI Duct Flow (scfm) & 17927 & 17466 & 14543 \\
\hline RK Rotation (rpm) & 0.2 & 0.2 & 0.8 (maximum) \\
\hline RK Pressure (in. w.c.) & -3.3 & -3.1 & -3.1 \\
\hline RK Oxygen (\%) & 6.9 & 9.1 & 9.3 \\
\hline SCC Oxygen (\%) & 5.8 & 7.7 & 7.8 \\
\hline Stack CO (ppm) & 7.7 & 3.8 & 3.8 \\
\hline Stack Oxygen (\%) & 8.5 & 10.6 & 10.4 \\
\hline Stack Opacity (\%RT) & 0.86 & 1.34 & 1.65 \\
\hline Scrubber Inlet Temperature $\left({ }^{\circ} \mathrm{F}\right)$ & 188 & 182. & 185 \\
\hline Quench Flow (gpm) & 369 & 368 & 375 \\
\hline Cyclone pH & 7.4 & 7.7 & 7.6 \\
\hline Scrubber Steam Flow (lb/hr) & 10,000 & 10,000 & 10,000 \\
\hline Scrubber Water Flow (gpm) & 70 & 70 & 68 \\
\hline
\end{tabular}


TABLE V

Summary of CIF Trial Burn Results

\begin{tabular}{|c|c|c|c|c|c|}
\hline Parameter & Condition 1 & Condition 2 & Condition 3 & Permit Limit & $\begin{array}{l}\text { Proposed } \\
\text { MACT } \\
\text { Standard }\end{array}$ \\
\hline \multicolumn{6}{|l|}{ Destruction \& Removal (\%) } \\
\hline Tetrachloroethylene & 99.99826 & 99.99975 & 99.99985 & 99.99 & \\
\hline Chlorobenzene & 99.99550 & 99.99934 & 99.99985 & 99.99 & \\
\hline Hexachloroethane & 99.99990 & 99.99993 & 99.99994 & 99.99 & \\
\hline Naphthalene & 99.99975 & 99.99991 & 99.99994 & 99.99 & \\
\hline Particulate (gr/dscf)@7\% $\mathrm{O}_{2}$ & 0.0025 & 0.0017 & 0.0020 & 0.08 & 0.015 \\
\hline Particulate (lb/hr) & 0.093 & 0.069 & 0.063 & 2.81 & \\
\hline $\mathrm{HCl}$ Emission (lb/hr) & 0.023 & 0.038 & 0.022 & 4.0 & \\
\hline $\mathrm{HCl}$ Control Efficiency (\%) & 99.99 & 99.98 & 99.98 & 99.0 & \\
\hline Cl Emission (lb/hr) & 0.0035 & 0.0078 & 0.0015 & 1.0 & \\
\hline $\mathrm{HCl} / \mathrm{Cl}$ (ppmv) & 0.27 & 0.47 & 0.30 & $\mathrm{NA}$ & 15 \\
\hline PCDD/PCDF@7\% O (ng/dscm) & 1.95 & 3.1 & 1.71 & $\mathrm{NA}$ & 0.2 \\
\hline $\begin{array}{l}\text { Semivolatile Metals }(\mu \mathrm{g} / \mathrm{dscm}) \\
(\mathrm{Cd} \text { and } \mathrm{Pb})\end{array}$ & 15.5 & 5.44 & 7.02 & NA & 100 \\
\hline $\begin{array}{l}\text { Low Volatile Metals }(\mu \mathrm{g} / \mathrm{dscm}) \\
(\mathrm{As}, \mathrm{Be}, \mathrm{Cr}, \mathrm{Sb})\end{array}$ & 18.1 & 7.75 & 9.90 & NA & 55 \\
\hline Mercury & 3871 & 2412 & 2247 & NA & 50 \\
\hline $\mathrm{CO}(\mathrm{ppm})$ & 8.1 & 7.7 & 3.8 & 100 & \\
\hline $\mathrm{CO}(\mathrm{lb} / \mathrm{hr})$ & 0.26 & 0.11 & 0.08 & 14.34 & \\
\hline $\mathrm{NOx}(\mathrm{lb} / \mathrm{hr})$ & 12.66 & 10.66 & 12 & 40 tons/yr. & \\
\hline
\end{tabular}


Communication during the preparation period and during the actual testing is essential. Shift briefings were conducted on all phases of activities, including the testing of the spiking systems on nonhazardous materials. Operator aids were prepared and posted at each sampling station which outlined personnel protection, spill response, sampling frequency and sample size. During the Trial Burn, daily briefing sheets were posted away from the Control Room to inform all personnel of the status of each test during each run. Radio contact was maintained so all testing personnel were immediately informed of waste feed cutoffs and other plant perturbations.

Use commercially available resources wherever possible. By buying pre-mixed chemical simulants, many man hours are saved and the potential for error is significantly reduced. The pre-mixed chemicals can be bench tested prior to the Trial Burn to ensure that corrosivity, compatibility, and pumpability problems are identified and corrected. Using experienced vendors for spiking operations provides for a more consistent flow and well documented results.

Conducting the mini-burns are very effective in preparing for the Trial Burn. They told us where our weaknesses and strengths were and we were able to manage accordingly.

\section{REFERENCES}

1. Savannah River Site Consolidated Incineration Facility Trial Burn Report (July 1997).

\section{FIGURES}

Figure 1. Flow Diagram of the Consolidated Incineration Facility. 